Contents lists available at JournalIICET

JPPI (Jurnal Penelitian Pendidikan Indonesia)

ISSN: 2502-8103 (Print)ISSN: 2477-8524(Electronic)

\title{
Stress and anxiety among late adulthood in Indonesia during COVID-19 outbreak
}

\author{
Ifdil Ifdil ${ }^{1}$, Verlanda Yuca $^{2}$, Frischa Meivilona Yendi ${ }^{3}$. \\ ${ }^{123}$ Universitas Negeri Padang
}

\begin{tabular}{l} 
Article Info \\
\hline Article history: \\
Received Sep $10^{\text {th }}, 2020$ \\
Revised Sep $29^{\text {th }}, 2020$ \\
Accepted Sep $29^{\mathrm{h}}, 2020$ \\
\hline
\end{tabular}

Keyword:

Stress

Anxiety

COVID-19

Rasch Analysis

\begin{abstract}
This study analyzes the condition of stress and anxiety in late adulthood in Indonesia during the COVID-19 pandemic based on demographics. The research used quantitative methods with an online survey by survey monkey program involved 669 respondents based on twelve ethnicities in Indonesia. The data of this research analysis by the Rasch analysis model. The results showed generally experienced stress and anxiety in the moderate category although some respondents also experienced stress and anxiety in mild and severe categories, and only a small proportion was in the normal category. The need for continued treatment requires counselors, psychologists, and other relevant therapists.
\end{abstract}

(C) 2020 The Authors. PublishedbyIICET.

Thisisan open accessarticleunderthe CC BY-NC-SA license (https://creativecommons.org/licenses/by-nc-sa/4.0

\section{Corresponding Author:}

Ifdil Ifdil,

Universitas Negeri Padang

Email: ifdil@konselor.org

\section{Introduction}

The entire world is troubled by the case of a deadly virus originating from Wuhan in China's Hubei Province, which emerged in late 2019 (Holshue et al., 2020). On January 11, China announced the first death caused by the new virus was a 61-year-old man, who was exposed in the seafood market (Who, 2020c). On 11 February, WHO announced the name for the new virus was COVID-19 (Organization, 2020), a few weeks later on 11 March 2020 around 114 countries were exposed to COVID-19, this condition caused WHO to declare COVID-19 as a pandemic (Organization, 2020). On February 14, 2020, a virus called "COVID-19" entered Indonesia through a visit of a Japanese citizen to Indonesia who transmitted to a woman who worked as a dance teacher, this resulted in COVID-19 starting to increase in Indonesia. The World Health Organization (WHO) declared it a pandemic only 2 and a half months after the epidemic spread throughout the world (Who, 2020a). WHO stated that the Public Health Emergency of International Concern on January 30, 2020(Organization, 2020; Who, 2020a).

The world is experiencing a health emergency, so health facilities and health services (Das, 2020) take the role of being the frontline in overcoming COVID-19. Das (2020) states when the world's best health services and global public health researchers are busy working on overcoming COVID-19 but are we prepared enough to deal with psychological and psychiatric problems in the post-pandemic period? Fear and anxiety are common psychological responses during disaster situations like this (Dong \& Bouey, 2020). However, the impact of prolonged social isolation can cause stress that ends in a pathological mental state (Goyal, Chauhan, Chhikara, Gupta, \& Singh, 2020). In addition, large-scale quarantine actions unprecedented in all major cities have negative psychosocial effects on the population (Brooks et al., 2020; Dong \& Bouey, 2020). 
In addition, countries experiencing worse recession (socioeconomic setbacks), lower middle-income countries such as India and Indonesia tend to face worse (Lai et al., 2020; Tosepu et al., 2020). Many proven social factors such as severe illness, prolonged hospitalization, death of a loved one, months of forced quarantine, loss of work, lack of supply, bad stigma (we will all be infected), especially those who are more vulnerable to stress and already suffering from mental illness (Brooks, et al., 2020; Das, 2020; Mak, Chu, Pan, Yiu, \& Chan, 2009). Das (2020) suggests that many patients in isolation wards experience excessive fear, anxiety and sleep disturbances during a hospital stay, even frontline health workers also show signs of anxiety and depression. But that is not enough, health workers who are quarantined significantly experience anxiety when dealing with patients with fever, irritability, insomnia, worsening work performance, and unwillingness to work or consideration of resignation (Bai et al., 2004). In addition, the effects of quarantine can cause posttraumatic stress in hospital staff up to 3 years later (Wu et al., 2009). Hospital staff examine depressive symptoms 3 years after quarantine and find $9 \%$ of high depressive symptoms and in the community nearly $60 \%$ of high depressive symptoms (Liu et al., 2012). Various negative responses were reported during the quarantine period: over 20\% (230 of 1057) reported fear, 18\% (Swainston, Chapman, Grunfeld, \& Derakshan, 2020) reported nervousness, $18 \%$ (186) reported grief, and 10\% (101) report guilt (Reynolds et al., 2008). Qualitative studies also identify a range of other psychological responses to quarantine, such as confusion (Braunack-Mayer, Tooher, Collins, Street, \& Marshall, 2013), fear and anger (Caleo et al., 2018), sadness (Wang et al., 2011), and anxiety-induced insomnia (Desclaux, Badji, Ndione, \& Sow, 2017).

Based on the presentation of the above conditions, the National Health Commission of China (Dong \& Bouey, 2020) issued a notice on January 26, 2020, providing guidance on the principles of psychological crisis intervention to reduce the psychosocial effects of the COVID-19 outbreak. This notification stipulates that psychological crisis interventions must be part of the public health response to the COVID-19 outbreak, through joint prevention and control mechanisms at the village, city and provincial levels, and the group must differentiate interventions. The intervention workforce comprises a psychological outreach team led by psychiatrists and mental health professionals, and a psychological support hotline team (Dong \& Bouey, 2020).

However, China has other major challenges to successfully implementing psychological crisis interventions, namely a shortage of mental health service providers (1,49 psychiatrists / 100,000 population and half of them have not yet got a medical degree, the lack of uneven health care nurses and the limitations posed by mass quarantine (Liang, Mays, \& Hwang, 2018). Volunteers set up many hotlines for psychological support, such as hospitals, universities, organizations, and various institutions with various levels of qualifications and experience (Dong \& Bouey, 2020). Coordinated and not adequately monitored and thus causes confusion for people need services and inefficient use of resources (Dong \& Bouey, 2020). The World Health iOrganization's strategic preparedness and response plan for COVID-19, has not yet established a strategy for meeting mental health needs in any form (Who, 2020b). When the virus spreads globally, governments must meet public mental health needs by developing and implementing a well-coordinated strategic plan to meet the needs during the COVID-19 pandemic (Dong \& Bouey, 2020).

Stress and anxiety are the dominant psychological aspects of the pandemic COVID - 19. Extraordinary situations such as epidemics and epidemics can cause stress and fear in people in various parts of the world (Asmundson \& Taylor, 2020). As in most countries that have been exposed to this pandemic, people in Indonesia feel the impact of the COVID-19 pandemic on a broader dimension of life. Many people begin to worry and feel they have been completely exposed to COVID-19 viruses, worried about their lives, worried about losing their jobs, afraid of losing the people closest to them. What's more news in various mass media (television, radio, newspapers) as well as social media which headlines focus on the number in individual centers and deaths emerged from COVID-19. The role of counselors, psychologists and psychiatrists are needed to reduce feelings of stress and anxiety (Dong \& Bouey, 2020) during the COVID-19 and postpandemic pandemics. Das (2020) suggests three main problems that must be addressed by fellow psychiatrists are: conducting research to produce new findings, (2) generating awareness and psychological readiness among the public and important service providers, (3) providing active psychological and psychiatric intervention to those who need it. This study aims to analyze the stress and anxiety conditions of adults in Indonesia during the COVID-19 pandemic based on gender, ethnicity, province, age, number of social media accounts, and length of internal access per day.

\section{Method}

This survey study involved 669 respondents comprising 12 ethnicities in Indonesia. This research was conducted in Indonesia, which has been known as a country that has many islands spread across 34 provinces. The demographic description of the respondents can be seen in Table 1. The survey is conducted on early 
February to early of April of 2020. Respondents were given an instrument comprising 21 stress statements related to COVID-19 and 21 statements of anxiety related to COVID-19 given online. Each respondent can choose one of four alternative answers provided and 40 minutes of the time given to complete the instrument. The survey on this study used the survey monkey program. This study uses two instruments, namely: stress and anxiety that focus on individual conditions related to COVID-19. This instrument was prepared by the Indonesian Institute for Counseling, Education and Therapy (IICET) by measuring three aspects, namely: 1) listening related to COVID-19, 2) viewing/reading related to COVID-19, and 3) imagining related to COVID19 respectively each aspect comprises seven items. The instrument uses a 4-point Likert scale with the number of items for each instrument 21 .

Table 1 Demographics of Research Respondents (N=669)

\begin{tabular}{|c|c|c|c|c|c|}
\hline Gender & Ethnicity & The province & Age & $\begin{array}{l}\text { Number of } \\
\text { Social } \\
\text { Media } \\
\text { Accounts }\end{array}$ & $\begin{array}{c}\text { Internet access per } \\
\text { day }\end{array}$ \\
\hline Male, $n=239$ & Java, $\mathrm{n}=189$ & $\begin{array}{l}\text { Nanggroe Aceh Darussalam, } \\
n=7\end{array}$ & $\begin{array}{l}25-40 \text { year, } \\
\mathrm{n}=466\end{array}$ & $1, \mathrm{n}=124$ & $1-2$ hours, $n=140$ \\
\hline \multirow[t]{22}{*}{ Female, $n=430$} & Sunda, $\mathrm{n}=85$ & North Sumatera, $\mathrm{n}=2$ & $\begin{array}{l}40-60 \text { year, } \\
n=203\end{array}$ & $1-3, n=422$ & $3-4$ hours, $n=252$ \\
\hline & Malay, $\mathrm{n}=77$ & West Sumatera, $\mathrm{n}=26$ & & $>3, \mathrm{n}=122$ & 5- 6 hours, $n=135$ \\
\hline & Betawi, $\mathrm{n}=14$ & Riau, $n=2$ & & & $>6$ hours, $n=141$ \\
\hline & Minang, $n=149$ & Riau Island, $\mathrm{n}=1$ & & & \\
\hline & Batak, $n=13$ & Jambi, $n=20$ & & & \\
\hline & Bugis, $n=9$ & Bengkulu, $\mathrm{n}=12$ & & & \\
\hline & Madura, $n=13$ & South Sumatera, $\mathrm{n}=9$ & & & \\
\hline & Sasak, n=24 & Lampung, $\mathrm{n}=24$ & & & \\
\hline & Bali, $n=1$ & Banten, $\mathrm{n}=4$ & & & \\
\hline & Tionghoa, $\mathrm{n}=4$ & Jakarta, $\mathrm{n}=14$ & & & \\
\hline & Others, $n=90$ & West Java, n=26 & & & \\
\hline & & Central Java, $n=12$ & & & \\
\hline & & East Java, $n=21$ & & & \\
\hline & & Yogyakarta, $n=3$ & & & \\
\hline & & Bali, $n=4$ & & & \\
\hline & & West Nusa Tenggara, $\mathrm{n}=25$ & & & \\
\hline & & West Kalimantan, $\mathrm{n}=1$ & & & \\
\hline & & South Kalimantan, $\mathrm{n}=3$ & & & \\
\hline & & South Sulawesi, $\mathrm{n}=3$ & & & \\
\hline & & North Maluku, $n=1$ & & & \\
\hline & & Papua, $n=3$ & & & \\
\hline & & No filling, $n=446$ & & & \\
\hline
\end{tabular}

In the stress aspect of listening related to COVID-19 with the SHC1 code that reads "I feel hard to calm down when listening to COVID-19". In the stress aspect of seeing/reading related to COVID-19 with SSC5 code that reads "I overreact to certain circumstances/activities when viewing/reading related to COVID-19". On the stress aspect of seeing/reading related to COVID-19 with SIC9 code that reads "I feel too uneasy when looking/reading about COVID-19". Meanwhile, one of the anxiety items related to COVID-19 is that I realize my mouth feels dry when I listen to COVID-19 (item code; AHC1). The instrument validation test results are presented in Table 2.

The validation test results in Table 1 show that the reliability of the stress instrument 1.00 is at a very good level. This is also supported by the separation index value which can arrange items into 15 sections, from the very high, high, medium, lowest and lowest. The unidimensional estimation through principal component analysis (PCA) identifies the raw variance value explained with a size of $56 \%$, this means that the instrument 
unidimensional condition has been reached > 40\%; (Boone, Stever, \& Yale, 2014; Linacre, 2011) and constructs on the instrument already represent to measure stress conditions related to COVID-19.

Table 2. Instrument Validation Test Results

\begin{tabular}{lcc}
\hline Estimation & \multicolumn{2}{c}{ Values } \\
\cline { 2 - 3 } Item Reliabilities & Stress & Anxiety \\
Person Reliabilities & 1.00 & .99 \\
Cronbach alpha (KR-20) & .92 & .93 \\
Separation index of Item & 94 & .96 \\
Separation index of Person & 15.40 & 11.34 \\
Mean Item & 3.76 & 3.63 \\
Mean Person & 0.00 & 0.00 \\
Mean INTFIT MNSQ Item & -1.46 & -2.06 \\
Mean INFIT MNSQ Person & 1.01 & 1.02 \\
Mean OUTFIT MNSQ Item & 1.01 & 1.00 \\
Mean OUTFIT MNSQ Person & 1.03 & 1.00 \\
Raw Variance Explained by measures & 1.03 & 1.00 \\
Raw Variance Unexplained by measures & $56.0 \%$ & $55.3 \%$ \\
Value Maximum EXTREME Person & $44.0 \%$ & $44.7 \%$ \\
Value Minimum EXTREME Person & 1 & 1 \\
\hline
\end{tabular}

Meanwhile, the reliability of the .99 anxiety instrument is at a very good level. This is also supported by the separation index value which can arrange items into 11 sections, from very high, high, medium, low and very low. The unidimensional estimation through principal component analysis (PCA) identifies the raw variance value explained with a size of $55.3 \%$, this means that the instrument unidimensional condition has been reached $>40 \%$ (Boone, et al., 2014; Sumintono \& Widhiarso, 2015) and constructs on the instrument are already representative for measuring anxiety conditions related to COVID-19.
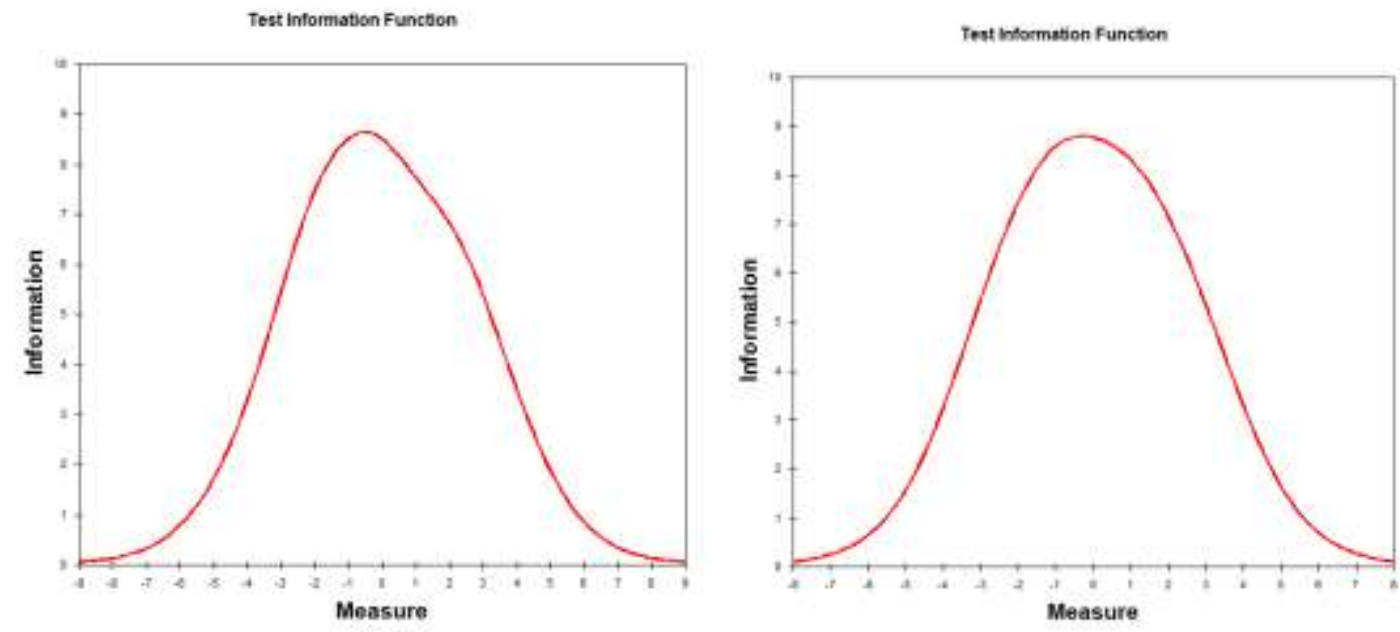

Figure 1. Test Information Function Stress

Figure 2. Test Information Function Anxiety

In Figure 1 and Figure 2 show that the quality of the instrument is very good for stress and anxiety measurement conditions related to COVID-19, it is known that the output of information collected by stress and anxiety instruments is at the maximum level for students with high, medium and low abilities and discloses information specifically for students are at high, medium and low stress and anxiety levels.

Table 2 shows The categorization of item fit and misfit on instrument stress and anxiety can be shown by comparing the MNSQ OUTFIT value of each instrument item with an average MNSQ OUTFIT value of +1.00 logit, meaning that 21 items are given to respondents of all items in each instrument stress and anxiety no one misfit. The following is conveyed by the quality of stress, and anxiety instruments using images.

This condition is also supported in Figure 3 and 4 . The choice of answers on the instrument is very often $=$ 4 , often $=3$, rarely $=2$, and never $=1$. The probability of choice of answers is rare and never tends to is by respondents, this condition is influenced by individual feelings. Figures 3 and 4 show that the response points 1 to 4 were understood by respondents, as seen from all the answers, they formed a normal curve and each had a peak. 


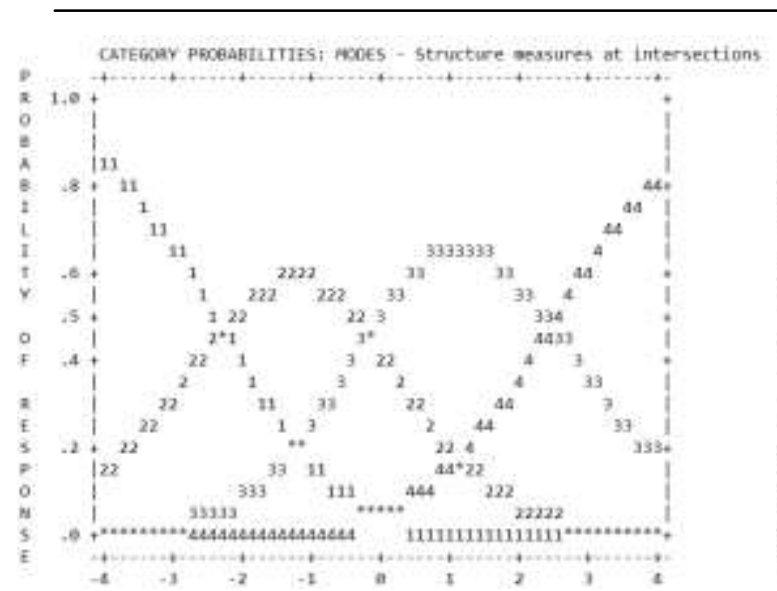

Figure 3. Probability of student answers on each choice answer stress

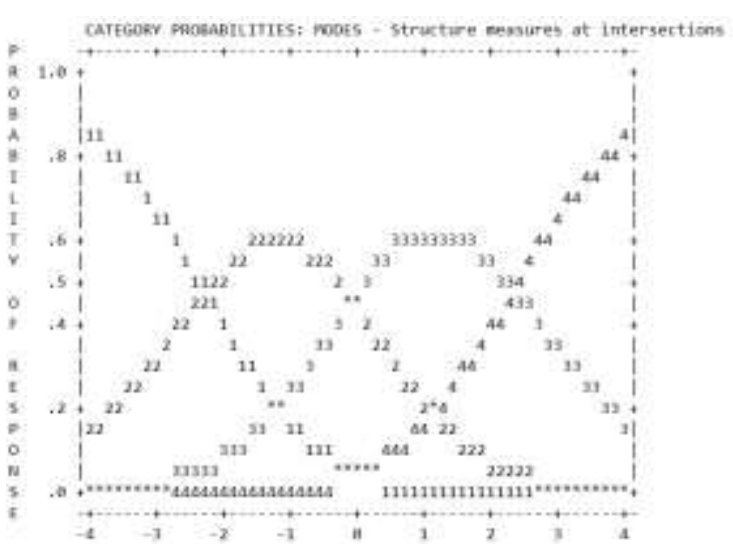

Figure 4. Probability of student answers on each choice answer anxiety

The research data were analyzed by Rasch model analysis were performed by Winsteps Program V.4.0. The analysis including three steps, namely: 1) testing stress conditions and individual anxiety using variable maps, 2) descriptive testing using subtotal specifications, and 3) testing perceptions based on demographics using Differential Item Functional (Bond \& Fox, 2015).

\section{Results and Discussions}

\section{Stress and anxiety conditions related to COVID-19 in Indonesia}

To evaluation of respondents' stress and anxiety levels we used the Wright Map method, to assess how each respondent responded to each item on the anxiety and stress scale. Figure 5 shows the stress maps variable, the left wright map describes the stress condition of the respondent and the right wright map describes the ability of stress items. On the left map, wright shows $1 \mathrm{SD}$ (S) / severe conditions above a little of logit 0 , meaning that the respondents stress conditions related to COVID-19 are in a mild state. While wright maps on the right show the quality of stressed items. On the left map wright is divided into three parts, namely: 1) Stress Hearing COVID-19, 2) Stress Sees COVID-19 (SSC), and 3) Stress Imagining COVID-19 (SIC).

Item SSC1 (-2.54 logit) is most answered by respondents because the statement of the item is often felt by all respondents and item SHC7 (+1.89 logit) is the item that is most difficult to answer correctly by respondents. Item SSC1 has a stressful statement that everyone feels the condition, while the statement "I feel hard to calm down when seeing/reading related to COVID-19" and vice versa with item SHC7 has a stressful statement that not everyone feels the condition, as for the statement "I am offended when I hear about COVID-19". However, wright maps on the left show that there are 10 respondents able to answer item SHC7, meaning that 10 respondents have very severe stress conditions. Meanwhile, severe conditions were 82 respondents with a logit range of +1.79 to $+0.28,410$ respondents were under moderate stress with a logit range of +0.23 to $-2.48,156$ respondents were in mild stress conditions with a logit range of -2.63 until -5.83 , and 11 respondents were under normal stress conditions related to COVID-19.

In Figure 6 shows the anxiety map variables, the left wright maps describe the respondent's anxiety condition and the right wright maps describe the anxiety items' abilities. On the left map, wright shows 1SD (S) / severe condition is below logit 0 , meaning that the respondent's anxiety condition related to COVID-19 is in a normal state. While wright maps on the right show the quality of anxiety items. On the left map Wright is divided into three parts, namely: 1) Anxiety Hearing COVID-19 (Yildırım \& Güler, 2020), 2) Anxiety Sees COVID-19, and 3) Anxiety Imagining COVID-19 (Cheng et al., 2020).

ASC4 items (-1.23 logit) are the easiest to answer by respondents because the statement of these items is often felt by all respondents and AHC3 items (+1.58 logit) are the items that are most difficult to answer by respondents. Item ASC4 state containing anxiety that everyone feels the condition, while the statement "I am worried and panic when seeing/reading about COVID-19" and vice versa with item AHC3 has a statement containing anxiety that not everyone feels the condition As for the statement "I have trembled (a sample of the hand) when I heard about COVID-19". However, wright maps on the left show that there are 14 respondents able to answer AHC3 items, meaning that 14 respondents had very severe anxiety conditions. Meanwhile, severe conditions there were 69 respondents with a logit range of +1.45 to $+0.20,412$ respondents were in anxious conditions with a logit range of +0.23 to $-2.48,104$ respondents were in a mild anxious condition with 
a logit range of -2.63 until -5.83 , and 70 respondents were in anxious condition with a logit range of -5.57 to 6.82 .
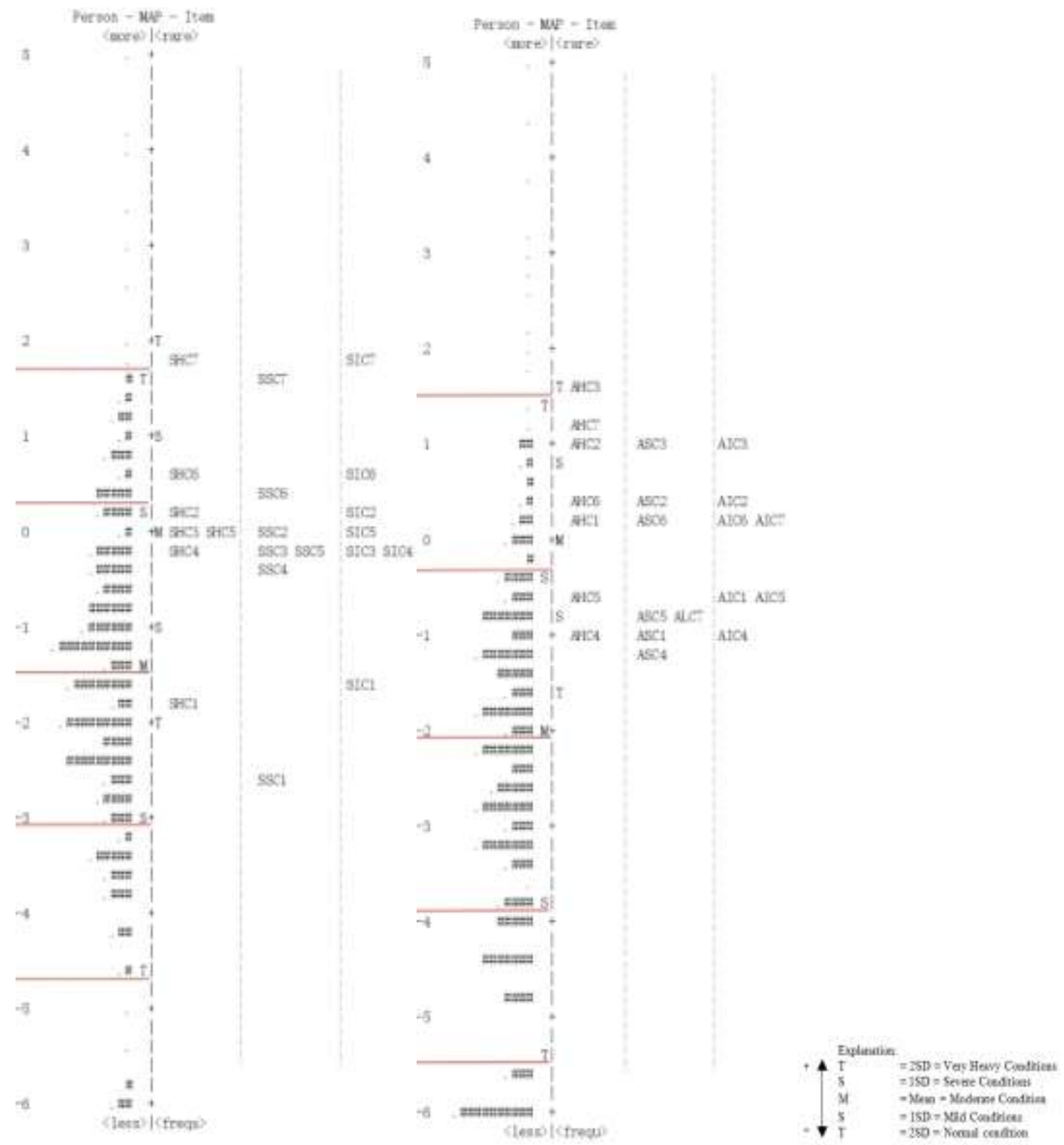

Figure 5. Variable Maps Stress

Figure 6. Variable Maps Anxiety

Comparing the distance between M-S-T (mean, 1SD and 2SD) on the above variable maps shows that on the left side of the map the distribution of respondents' ability is lower than the distribution of the item's level of ability on the right. In table 2 also shows a significant difference between mean person and mean item, for example stress instruments that have a mean measure difference of -1.46 and anxiety instruments differ -2.06 , meaning that the average respondent's condition is in a mild state related to the COVID-19 pandemic problem. More it can be seen that the minimum value of extreme stress and anxiety is more than the maximum value, meaning that 11 (respondent stress) and 54 (respondent anxiety) are in normal condition related to the COVID-19 pandemic problem.

\section{Stress and anxiety conditions based on demographics}

The entire world is nervous about the case of a deadly virus originating from Wuhan in China's Hubei Province which emerged in late 2019 (Holshue, et al., 2020) and February 14, 2020, a virus called "COVID19" began to enter Indonesia. COVID-19 has become a global problem that requires all levels of society to play a role in overcoming this problem. The World Health Organization (WHO) declared it a pandemic only 2 and a half months after the disease outbreak (Who, 2020a). The following is a descriptive stress and anxiety condition in Indonesia. 
Table 3. Descriptive Stress Test Results Based on Gender

\begin{tabular}{lllllll}
\hline Person Count & $\begin{array}{l}\text { Mean } \\
\text { Measure }\end{array}$ & $\begin{array}{l}\text { S.E. } \\
\text { Mean }\end{array}$ & Median & $\begin{array}{l}\text { Model } \\
\text { Separation }\end{array}$ & $\begin{array}{l}\text { Model } \\
\text { Reliability }\end{array}$ & Code \\
$\mathbf{6 6 9}$ & -1.54 & .07 & -1.53 & 3.57 & .93 & $*$ \\
$\mathbf{2 3 9}$ & -1.86 & .12 & -1.91 & 3.60 & .93 & $\mathrm{M}$ \\
$\mathbf{4 3 0}$ & -1.37 & .08 & -1.29 & 3.49 & .92 & $\mathrm{~F}$ \\
\hline
\end{tabular}

Table 4. Descriptive Anxiety Test Results Based on Gender

\begin{tabular}{lllllll}
\hline Person Count & $\begin{array}{l}\text { Mean } \\
\text { Measure }\end{array}$ & $\begin{array}{l}\text { S.E. } \\
\text { Mean }\end{array}$ & Median & $\begin{array}{l}\text { Model } \\
\text { Separation }\end{array}$ & $\begin{array}{l}\text { Model } \\
\text { Reliability }\end{array}$ & Code \\
$\mathbf{6 6 9}$ & -2.43 & .08 & -2.26 & 2.94 & .90 & $*$ \\
$\mathbf{2 3 9}$ & -2.81 & .15 & -2.27 & 2.74 & .88 & M \\
$\mathbf{4 3 0}$ & -2.21 & .10 & -2.12 & 3.05 & .90 & $\mathrm{~F}$ \\
\hline
\end{tabular}

Explanation:

$\begin{array}{ll}\mathrm{M} & =\text { Male } \\ \mathrm{F} & =\text { Female }\end{array}$

Tables 3 and 4 show a total of 669 respondents (male $=239$ and female $=430$ ). In table 3 the mean size of male is smaller than that of female, meaning that female are more stressed over the COVID-19 pandemic than male. In contrast to the value of S.E Mean that male (.12) are greater than female (.08), meaning that errors or deviations occur on average in male samples. However, the reliability of male is slightly higher than that of female, meaning that the quality of answers given by male and female respondents is very good.

In Table 4 the mean size of male is smaller than that of female, meaning that female are more anxious about the COVID-19 pandemic than male. In contrast to the value of S.E Mean that male (.15) are greater than female (.10), meaning that errors or deviations occur on average in a male sample. The results of the reliability of male are lower than female, meaning that the quality of answers given by female is better than male. This means that female experience more stress and anxiety related to COVID-19 compared to male.

Medical staff and the public have experienced psychological problems, including anxiety, depression, and stress resulting from an increase in the number of deaths, massive quarantine, social distancing, job loss, and the negative stigma associated with COVID-19 (Brooks, et al., 2020; Naeem et al., 2016). Stress and anxiety conditions based on ethnicity in Indonesia are presented in table 5 below.

Table 5 shows that the most dominant respondents were Javanese $(n=189)$ and Minanges $(n=149)$. However, the ones who gave the best response came from Sundanese and Malays, seen from reliability values of .91 to .94 compared to other reliability values. When viewed from the stress-related conditions of COVID19 , Chinese ethnics of 4 people were more stressed in facing the COVID-19 situation compared to other ethnic groups, as seen from the mean measure of -1.12 logit. Meanwhile, the respondents who felt the least stress came from the ethnic Balinese ( -3.59 logit; $n=1)$, but could not a benchmark because the respondents were only one person. Besides ethnic Balinese, there are two ethnic groups who are not stressed with COVID-19 conditions: Madura (-2.83 logit; $\mathrm{n}=13)$ and Bugis $(-2.53$ logit; $\mathrm{n}=9)$.

When viewed from the anxiety related to COVID-19, Sundanese ethnicity numbering 85 people tended to be nous about COVID-19 situations compared to other ethnic groups, as seen from the mean measure of -2.22 logit. In a stressful condition, one of the ethnic Balinese $(-4.01$ logit; $n=1)$ was at least anxious and two ethnicities who were not anxious about COVID-19 conditions: Madura (-3.28 logit; $n=13)$ and Bugis $(-3.62$ logit; $n=9)$. Differences in stress and anxiety based on ethnicity in answering instruments are clarified using the graph presented in Figure 7.

Figure 7 shows alignment with table 5 that Chinese ethnic group of 4 people are more stressed in facing the COVID-19 situation compared to other ethnic groups, seen from the graph with code 11 and vice versa the Balinese ethnic graph (code 10) is the least stressed ethnic group and worry when the COVID-19 situation. Several approaches that can overcome COVID-19 by increasing community resilience related to COVID-19, one of which can be used is Cognitive Behavior Therapy (CBT) can increase resilience (Padesky \& Mooney, 2012). Resilience is the ability of individuals to rise from adversity, misfortune (MacInnis \& Gibala, 2017), post-disaster (Habibah, Lestari, Oktaviana, \& Nashori, 2018) and learn in responding to disasters when they occur again (Cutter et al., 2008). Cognitive Behavior Therapy (CBT) has also been adapted for cultural and sub-cultural use (Naeem, et al., 2016). In agreement with (Ifdil et al., 2018) the condition of female resilience is higher than that of male in West Sumatra, this is because of the role of the Minangkabau culture, in which the Minangkabau community adheres to a matrilineal kinship system to make female in Minangkabau become 
strong, hard, wise, independent in extreme conditions or misery. Stress and anxiety conditions by the province of residence in Indonesia are presented in table 6.

Table 5.Descriptive Stress and Anxiety Test Results Based on Ethnicity

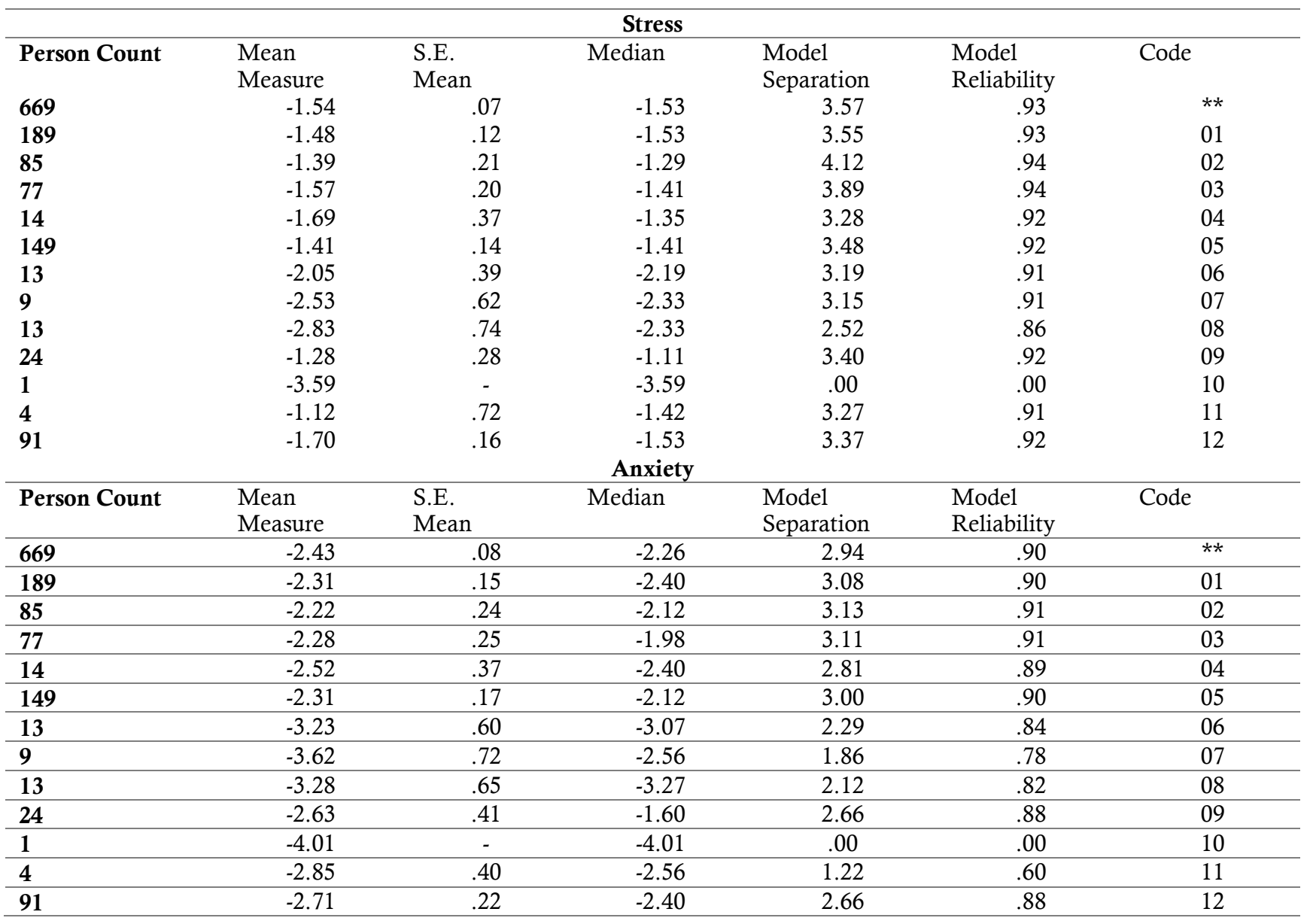

Explanation:

$\begin{array}{llll}01 & 07 & =\text { Bugis } \\ 02 & \text { = Java } & 07 & =\text { Madura } \\ 03 & \text { S Malay } & 08 & =\text { Sasak } \\ 04 & \text { = Betawi } & 09 & =\text { Bali } \\ 05 & \text { = Minang } & 10 & =\text { Tionghoa } \\ 06 & \text { = Batak } & 11 & =\text { Others }\end{array}$

Table 6 shows that many respondents did not fill in data related to the province of residence with 446 people. Based on stress conditions, there were 4 provinces that experienced the highest stress during the COVID-19 pandemic: South Sulawesi $(-.74$ logit; $\mathrm{n}=3)$, Banten $(-.84$ logit; $\mathrm{n}=4)$, West Sumatra $(-.86$ logit; $\mathrm{n}$ $=26)$, and Jambi $(-.98$ logit; $n=20)$. Meanwhile, the respondents who felt the least stress came from the DI Yogyakarta Province $(-2.88$ logit; $\mathrm{n}=3$ ), but could not a benchmark because there were only three respondents. Besides the Province of DI Yogyakarta there is one Province which is not stressed by COVID-19 conditions which can a benchmark: DKI Jakarta $(-1.74$ logit; $\mathrm{n}=24)$.

In line with the stress conditions of Banten Province (-1.02 logit; $n=4)$, South Sulawesi $(-1.50 \operatorname{logit} ; n=3)$, West Sumatra $(-1.51$ logit; $n=26)$, and Jambi $(-1.59$ logit; $n=20)$ experiencing anxiety. Based on these conditions, it can be stated that four provinces in Indonesia experience excessive stress and anxiety compared to other provinces. This condition is caused by unprecedented large-scale quarantine actions in all major cities which have negative psychosocial effects on the population (Dong \& Bouey, 2020). The researchers found that group threats (eg, natural disasters and epidemic diseases) made community groups caring for each other highly desirable and increased social solidarity ( $\mathrm{Li}$, Wang, Xue, Zhao, \& Zhu, 2020). Conditions in China Many Provinces (Sichuan, Shandong Province, etc.) formed medical teams to assist Hubei Province, which was the area most severely affected (Li, et al., 2020). Many people donated money and medical equipment 
supplies to the Hubei Red Cross to support the handling of COVID-19. Next, stress and anxiety conditions are based on age, several social media accounts, duration of internet access per day through the following graph

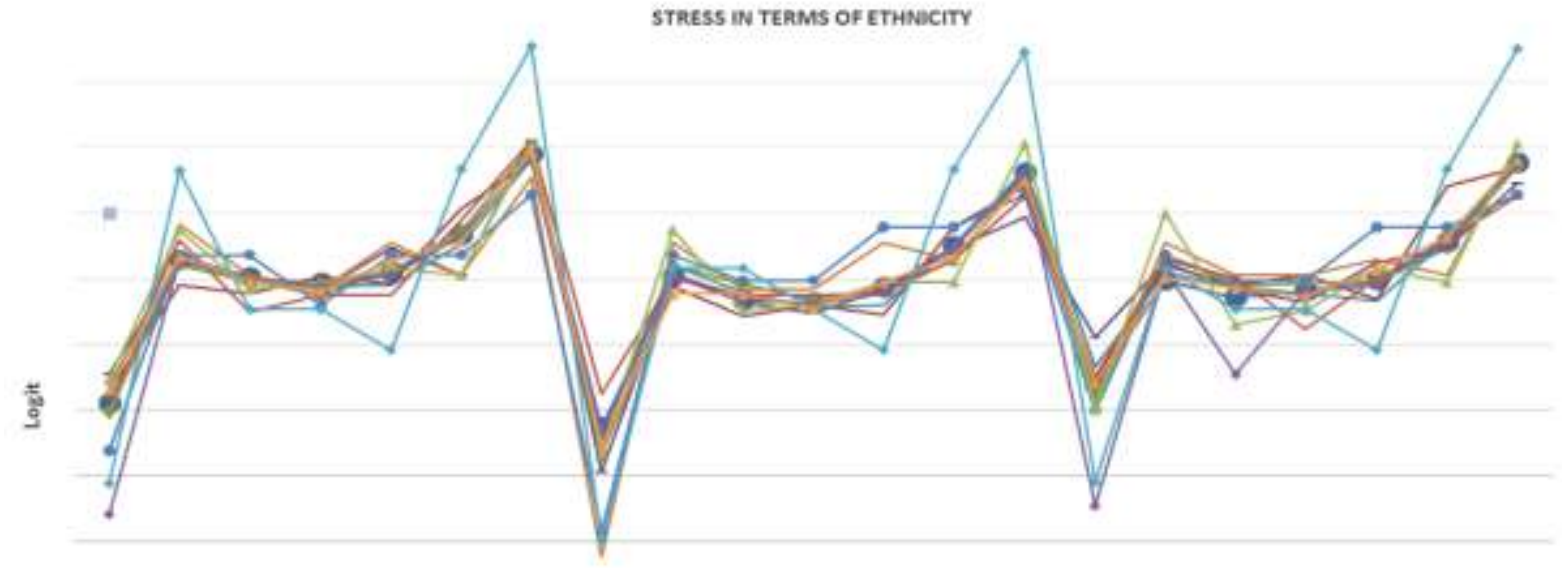

\begin{tabular}{|c|c|c|c|c|c|c|c|c|c|c|c|c|c|c|c|c|c|c|c|c|c|}
\hline & SHC1 & SHC2 & SHE3 & SHCA & SACS & $\sec 6$ & Sक्रC7 & $\operatorname{sesc} 1$ & ssc2 & ssca 3 & $53<4$ & $\operatorname{ssc5}$ & $\operatorname{ssc} 0$ & $5 s \mathrm{Cl}$ & SIC1 & $\operatorname{sic} 2$ & $\sec 3$ & SiC4 & SCS & 5106 & sicy \\
\hline+1 & -2.91 & 0,28 & 0,02 & $-0,00$ & 0,09 & 0.66 & 2,89 & $-2,26$. & 0,03 & $-0,34$ & -0.37 & $-0,15$ & $0,4 n$ & 1.61 & -1.63 & $-0,04$ & $-0,3$ & $-0,19$ & -0.03 & 0.55 & .76 \\
\hline+-3 & -2.02 & 0.2 & $-0,04$ & -0.25 & 0,12 & 0,72 & as & -2.72 & 0.2 & $-0,07$ & -0.33 & $-0,14$ & 0.27 & 1.55 & $-1,76$ & 0,35 & $-0,11$ & $-0,07$ & 203 & 847 & 1,71 \\
\hline-5 & $-1,67$ & 0,34 & 0,01 & $-0,12$ & $-0,11$ & 0,53 & 1,82 & $-2,4$ & 0,2 & $-0,21$ & $-0,46$ & 0,41 & 0,45 & 1,66 & $-1,37$ & 0,09 & $-0,13$ & $-0,24$ & $-0,35$ & 0,59 & 1,76 \\
\hline-6 & 2.19 & 0,84 & 0,05 & $-0,16$ & 0.56 & 0,06 & 2,56 & $-4,25$ & 0,56 & -0.16 & $-0,16$ & 0,56 & 0,3 & 1.58 & -1.93 & 0,56 & 0,05 & 0.06 & 0,3 & 0,06 & 2,05 \\
\hline$\leftrightarrow 7$ & 2.02 & 0,37 & 0,37 & 0,39 & 0,37 & 0,37 & 1,29 & $-3,86$ & 0,37 & 0,02 & 0,02 & 0,8 & $\mathrm{D}, \mathrm{B}$ & 1,29 & 2,01 & 0,37 & 0,02 & 0,02 & 0,8 & 0,8 & 1,29 \\
\hline+-10 & -3.61 & 0,211 & $-0,04$ & $-0,12$ & 0.06 & 0.63 & 1,59 & -2 & 0,07 & $-0,29$ & $-0,4$ & $-0,23$ & 0,46 & 1.50 & $-3,48$ & 0,14 & $-1,47$ & $-0,19$ & $-0,1$ & 0,64 & 1,70 \\
\hline+-11 & 3,12 & 1,06 & $0,4 E$ & 0,46 & 1,08 & 1,68 & 3,50 & 3,96 & 0,17 & 0,17 & $0,4 E$ & 1,08 & 1,08 & 3,47 & 3,3 & 0,17 & 0,40 & 0,46 & 1,08 & 1.68 & 3,52 \\
\hline-12 & -1.71 & 0,33 & $-0,04$ & -0, III & 0.26 & 0,36 & 1,93 & $-2,57$ & -0.24 & -0.24 & $-0,47$ & $-0,05$ & 0.33 & 1,49 & $-1,59$ & 0,01 & $-0,15$ & $-0,27$ & 0.13 & 0,64 & 1,82 \\
\hline 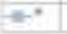 & 1 & & & & & & & & & & & & & & & & & & & & \\
\hline
\end{tabular}

\section{Anxiety In Terms of Ethnicity}

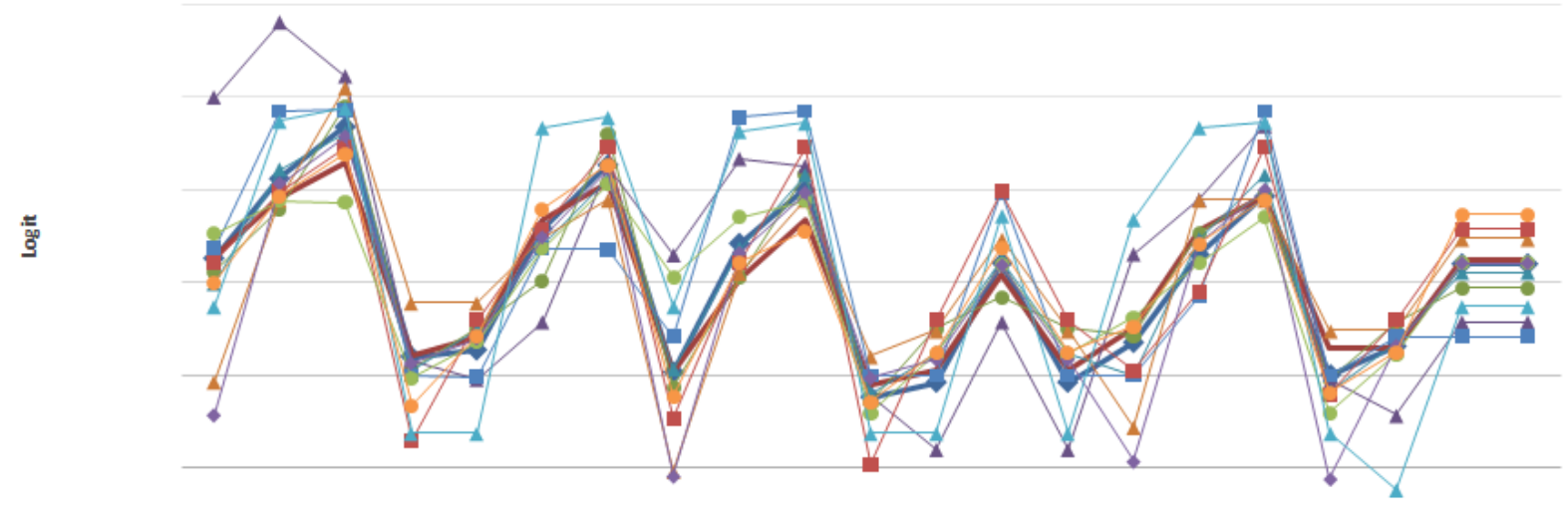

\begin{tabular}{|c|c|c|c|c|c|c|c|c|c|c|c|c|c|c|c|c|c|c|c|c|c|}
\hline & $\mathrm{CC}$ & & & $C 4$ & 5 & C6 & C7 & $\mathrm{Cl}$ & C2 & ASC3 & C4 & ASC5 & ASC6 & C7 & C1 & C2 & C3 & C4 & C5 & IC6 & IC7 \\
\hline & & & & & & & & & & & & & & & & & & & & & \\
\hline & & & & & & & & & & & & & & & & & & & & & \\
\hline 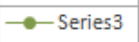 & & & & & & & & & & & & & & & & & & & & & \\
\hline$\star s$ & & & & 84 & & & & & & & & & 42 & & & & & 05 & & 2 & .42 \\
\hline 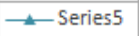 & & & & 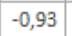 & & & & & & & & & & \begin{tabular}{|c|}
$-0,75$ \\
\end{tabular} & & & & 17 & & & 11 \\
\hline - & & & & & & & & & & & & & & & & & & & & & \\
\hline 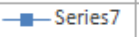 & & & & & & & & & & & & & & $\mid-1,01$ & & & & 1 & & & \\
\hline-5 & & & & 1,71 & & & & & & & & & & & & & & 21 & & 58 & \\
\hline$\bullet$ & & & & & & & & & & & & & & -0 & & & & 1,4 & & & \\
\hline 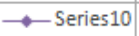 & & & & & & & & & & & & & & & & & & & & & \\
\hline-5 & $-0,2$ & & & 1,6 & & & & & & & & & & & & & & & & & \\
\hline 12 & & & & 32 & & & & 22 & 22 & & 29 &,, 14 & 0,30 & 0,14 & $-0,46$ & 0,43 & 189 & 1,19 & 0,74 & 74 &,, 74 \\
\hline
\end{tabular}

Figure 7. Stress and Anxiety Conditions Related to COVID-19 Based on Ethnicity 
In Figure 8 there are two lines that make up the graph, blue with code $1=25-40$ Years and code $2=40-60$ Years. From the pictures, the age range of 25-40 years is more dominant than the age range of 40-60 years. In addition, there is one statement that best describes stress related to COVID-19, item SHC7 which reads "I am offended when I hear about COVID-19".

\section{STRESS IN TERMS OF AGE}

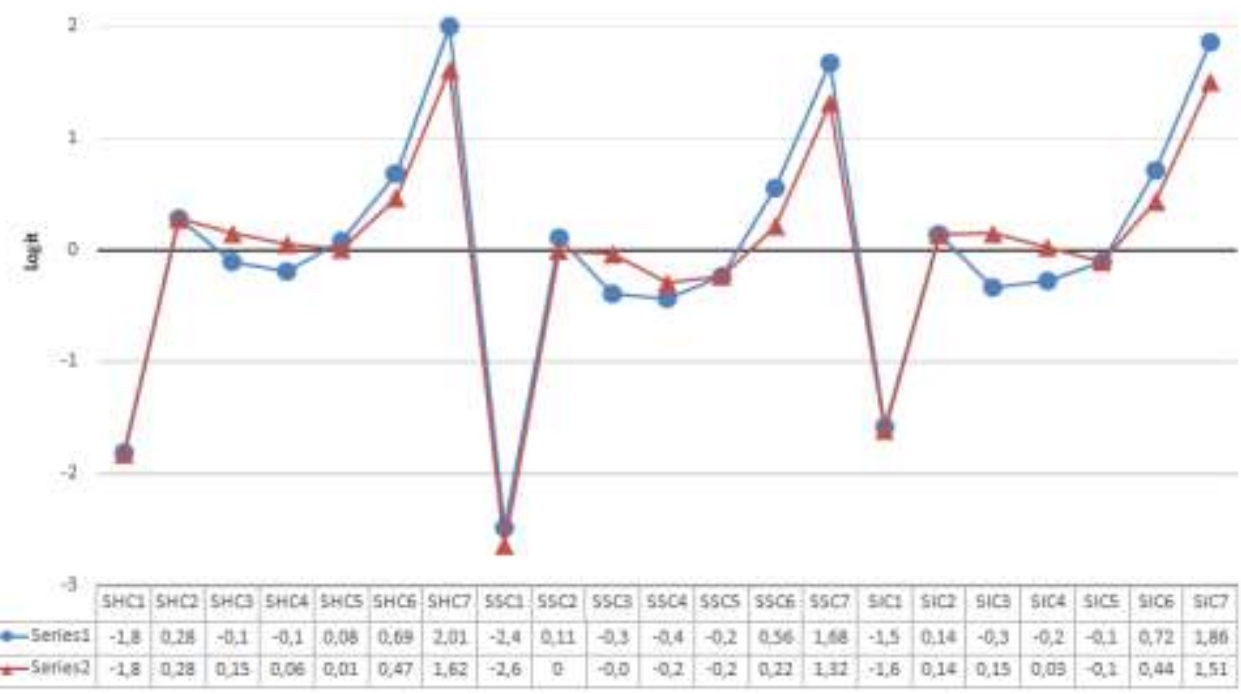

ANXIETY IN TERMS OF AGE

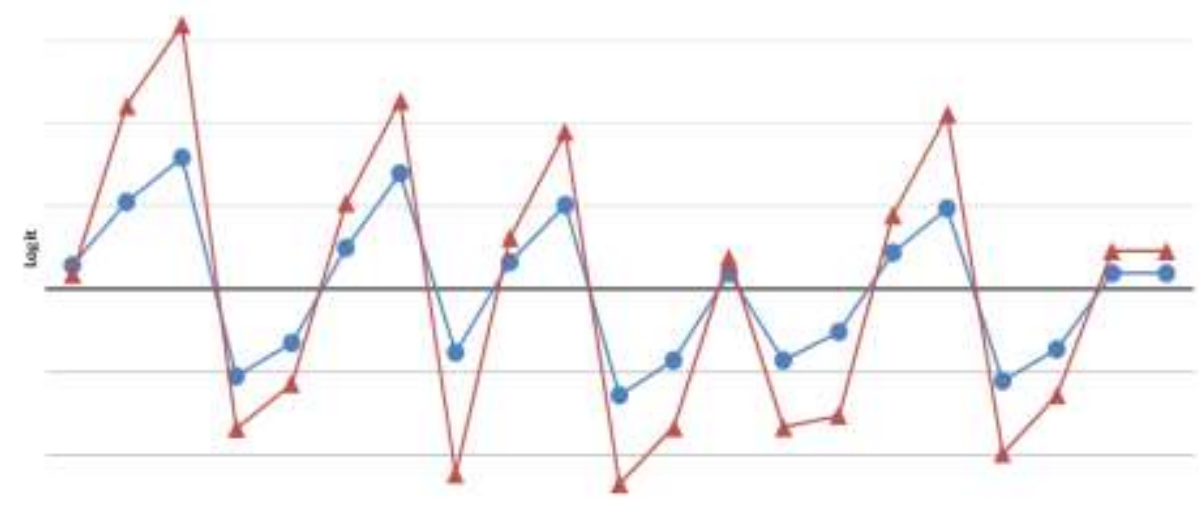

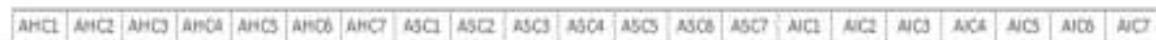

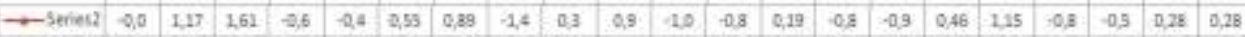

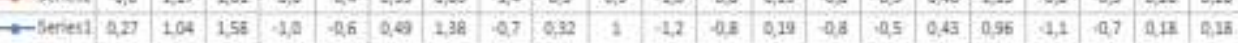

Figure 8. Stress and Anxiety Conditions by Age

The age range of 40-60 years feels more anxious about the COVID-19 pandemic situation compared to the age of 25-40 years. The dominant red line is higher than the blue line and there is one statement that best describes anxiety related to COVID-19, the AHC3 item that reads "I have been trembling (a hand example) when I hear about COVID-19". Isolation strategies are used throughout the world to limit the spread of COVID-19, but social isolation makes stressful conditions increase and is likely to cause emotions (Brooks, et al., 2020; Naeem, Irfan, \& Javed, 2020). In addition, the economic crisis exacerbated mental and emotional health problems in all countries, for example in Indonesia the economic crisis was very apparent because many people lost their jobs, plus the work of Indonesian people relied on social interaction. When viewed in terms of age (Wang, et al., 2011) found no significant differences between groups of undergraduate students (20-25 Years) who were quarantined in terms of post-traumatic stress symptoms or general mental health 
problems. Contradiction if that is quarantined by an adult who has the responsibility to work and provide for his family (Brooks, et al., 2020).

In figure 9 there are three lines that make up the graph, red with code 1 ( 1 account), green line code 2 (2-3 accounts), and purple line code 3 (> 3 accounts). From the picture the green line is more stressful and anxious than the other lines, meaning that individuals who have 2-3 social media accounts will be more stressed than those who have one social media account and too many social media accounts. In terms of age-based stress conditions, items SHC7 (stress) and AHC3 (anxiety) are also the dominant problems in stress and anxiety conditions based on the number of social accounts related to COVID-19. Based on the findings that both items need to be intervened through the role of all social services (counselor, psychologist, and psychiatrist) (Das, 2020) to reduce stress conditions that make individuals offended when listening to COVID-19 and anxious conditions that make hands tremble when hearing about COVID-19.

This condition is caused by "infodemic" information overload (eg/hoaxes) on social media and elsewhere that poses a substantial risk to public mental health during psychological crises (Dong \& Bouey, 2020). In the research of (Li, et al., 2020) states that people overestimate attitudes and prejudices, when they feel more vulnerable to disease transmission. As for one approach to overcoming COVID-19 through telemedicine, this approach can a solution to overcome the psychological crisis, given the widespread use of smartphones and internet access, where the internet is used by around 3.7 billion people worldwide (Internet World Stats, 2016). In the millennial era, the number of social media accounts is related to the length of internet access per day, this is because many individuals use the internet to access social networking sites in communicating or interacting and looking for news, such as Facebook, WhatsApp, Twitter, and Instagram (Beyens, Frison, \& Eggermont, 2016).

In figure 10 there are four lines that make up the graph, red with code 1 (1-2 hours), green line code 2 (2-4 hours), purple line code 3 (5-6 hours), and blue line code 4 ( $>6$ hours). The picture shows that the blue line is more stressful and anxious than the other lines, meaning that individuals who access the internet for over 6 hours per day are more likely to experience stress and anxiety than individuals who access the internet for 1-5 hours in one day. The same study by Dong \& Bouey (2020) suggests challenges for many developing countries in overcoming COVID-19, for example, telemedicine can be used as a solution to overcome the psychological crisis, given the widespread use of smartphones and internet access. Several approaches that can overcome COVID-19 by increasing community resilience related to COVID-19, one of which can be used is Cognitive Behavior Therapy (CBT) can increase resilience (Padesky \& Mooney, 2012).

Table 6.Stress Descriptive Test Results by Province in Indonesia.

\begin{tabular}{|c|c|c|c|c|c|c|}
\hline \multicolumn{7}{|c|}{ Stress } \\
\hline Person Count & Mean & S.E. & Median & Model & Model & Code \\
\hline & Measure & Mean & & Separation & Reliability & \\
\hline 669 & -1.54 & .07 & -1.53 & 3.57 & .93 & $* *$ \\
\hline 446 & -1.64 & .09 & -1.66 & 3.60 & .93 & 00 \\
\hline 7 & -1.35 & .49 & -1.91 & 3.16 & .91 & 01 \\
\hline 2 & -1.23 & .30 & -1.23 & .00 & .00 & 02 \\
\hline 26 & -.86 & .26 & -1.05 & 3.51 & .92 & 03 \\
\hline 2 & -1.98 & 1.39 & -1.98 & 3.26 & .91 & 04 \\
\hline 1 & -2.05 & - & -2.05 & .00 & .00 & 05 \\
\hline 20 & -.98 & .30 & -.93 & 3.42 & .92 & 06 \\
\hline 12 & -1.38 & .56 & -1.17 & 3.86 & .94 & 07 \\
\hline 9 & -1.25 & .94 & -1.41 & 3.62 & .93 & 08 \\
\hline 24 & -1.74 & .31 & -2.05 & 3.58 & .93 & 10 \\
\hline 4 & -.84 & .52 & -.76 & 2.39 & .85 & 11 \\
\hline 14 & -1.84 & .36 & -2.19 & 3.16 & .91 & 12 \\
\hline 26 & -1.27 & .36 & -1.05 & 4.35 & .95 & 13 \\
\hline 12 & -1.45 & .35 & -1.48 & 2.94 & .90 & 14 \\
\hline 21 & -1.59 & .38 & -1.29 & 2.97 & .90 & 15 \\
\hline 3 & -2.88 & 2.13 & -1.17 & 2.53 & .87 & 16 \\
\hline 4 & -1.84 & .74 & -1.76 & 3.10 & .91 & 17 \\
\hline 25 & -1.12 & .26 & -1.05 & 3.34 & .92 & 18 \\
\hline 1 & -1.63 & - & -1.63 & .00 & .00 & 20 \\
\hline 3 & -1.31 & .68 & -.93 & 2.48 & .86 & 21 \\
\hline 3 & -.78 & .30 & -.82 & .75 & .36 & 26 \\
\hline 1 & -1.53 & - & -1.53 & .00 & .00 & 32 \\
\hline 3 & -1.49 & .11 & -1.53 & .00 & .00 & 33 \\
\hline
\end{tabular}

Anxiety 


\begin{tabular}{|c|c|c|c|c|c|c|}
\hline Person Count & $\begin{array}{c}\text { Mean } \\
\text { Measure }\end{array}$ & $\begin{array}{l}\text { S.E. } \\
\text { Mean }\end{array}$ & Median & $\begin{array}{c}\text { Model } \\
\text { Separation }\end{array}$ & $\begin{array}{c}\text { Model } \\
\text { Reliability }\end{array}$ & Code \\
\hline 669 & -2.43 & .08 & -2.26 & 2.94 & .90 & $* *$ \\
\hline 446 & -2.57 & .10 & -2.56 & 2.87 & .89 & 00 \\
\hline 7 & -2.29 & .79 & -2.56 & 3.84 & .94 & 01 \\
\hline 2 & -2.12 & .00 & -2.12 & .00 & .00 & 02 \\
\hline 26 & -1.51 & .36 & -1.17 & 3.34 & .92 & 03 \\
\hline 2 & -3.85 & 2.97 & -3.85 & 2.01 & .80 & 04 \\
\hline 1 & -2.26 & - & -2.26 & .00 & .00 & 05 \\
\hline 20 & -1.59 & .47 & -1.29 & 3.47 & .92 & 06 \\
\hline 12 & -2.14 & .56 & -1.99 & 3.55 & .93 & 07 \\
\hline 9 & -1.49 & 1.02 & -.88 & 3.75 & .93 & 08 \\
\hline 24 & -2.40 & .42 & -2.48 & 3.17 & .91 & 10 \\
\hline 4 & -1.02 & .40 & -.83 & 1.74 & .75 & 11 \\
\hline 14 & -2.46 & .37 & -2.19 & 2.80 & .89 & 12 \\
\hline 26 & -2.02 & .39 & -2.41 & 3.28 & .91 & 13 \\
\hline 12 & -2.31 & .59 & -2.06 & 2.78 & .89 & 14 \\
\hline 21 & -2.75 & .47 & -2.12 & 2.44 & .86 & 15 \\
\hline 3 & -2.87 & 2.00 & -1.47 & 2.38 & .85 & 16 \\
\hline 4 & -2.73 & .81 & -3.13 & 2.81 & .89 & 17 \\
\hline 25 & -2.41 & .40 & -1.60 & 2.77 & .88 & 18 \\
\hline 1 & -1.94 & - & -1.94 & .00 & .00 & 20 \\
\hline 3 & -3.30 & 1.76 & -1.72 & 2.04 & .81 & 21 \\
\hline 3 & -1.50 & .40 & -1.60 & 1.21 & .59 & 26 \\
\hline 1 & -2.56 & - & -2.56 & .00 & .00 & 32 \\
\hline 3 & -1.73 & .25 & -1.97 & .00 & .00 & 33 \\
\hline
\end{tabular}

Explanation:

$\begin{array}{llll}01 & =\text { Nanggroe Aceh Darussalam } & 16 & =\text { Yogyakarta } \\ 02 & \text { = North Sumatera } & 17 & =\text { Bali } \\ 03 & =\text { West Sumatera } & 18 & =\text { West Nusa Tenggara } \\ 04 & \text { = Riau } & 20 & =\text { West Kalimantan } \\ 05 & \text { = Riau Island } & 21 & =\text { South Kalimantan } \\ 06 & =\text { Jambi } & 26 & =\text { South Sulawesi } \\ 07 & =\text { Bengkulu } & 32 & =\text { North Maluku } \\ 08 & =\text { South Sumatera } & 33 & =\text { Papua } \\ 10 & =\text { Lampung } & 14 & =\text { Central Java } \\ 11 & \text { = Banten } & 15 & =\text { East Java } \\ 12 & =\text { Jakarta } & 00 & =\text { No Filling }\end{array}$

$13=$ West Java

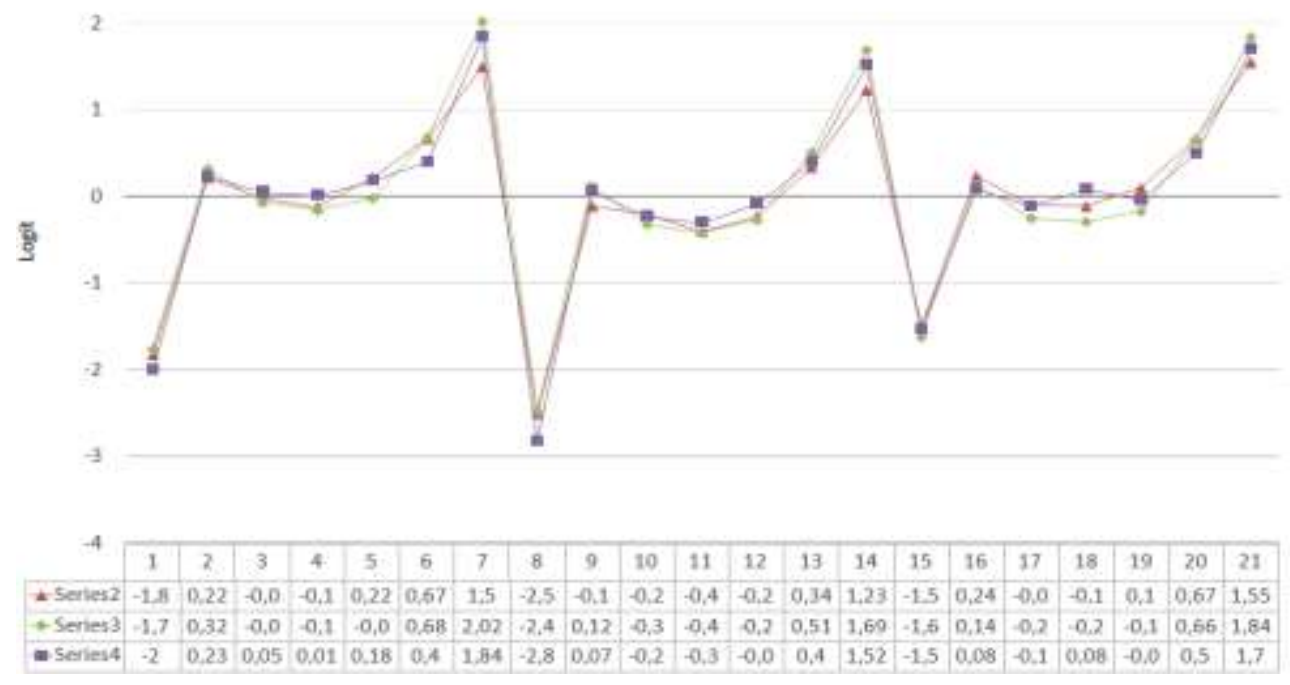



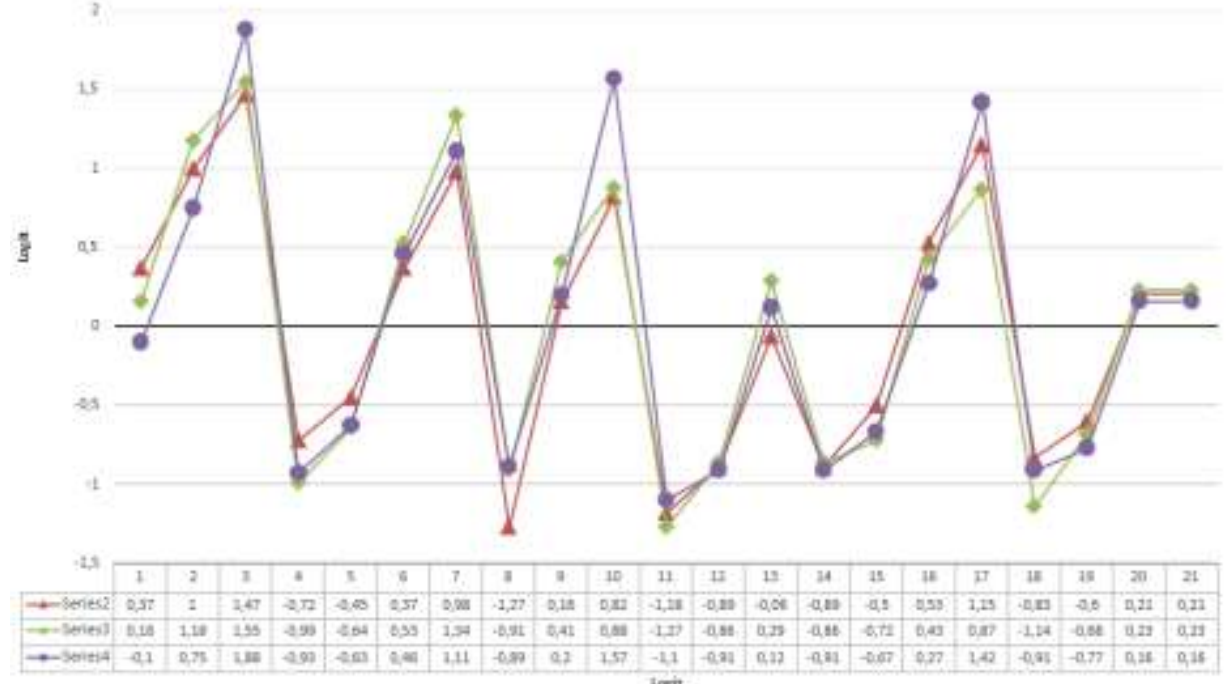

Figure 9. Stress and Disease Conditions Based on Number of Social Media Accounts
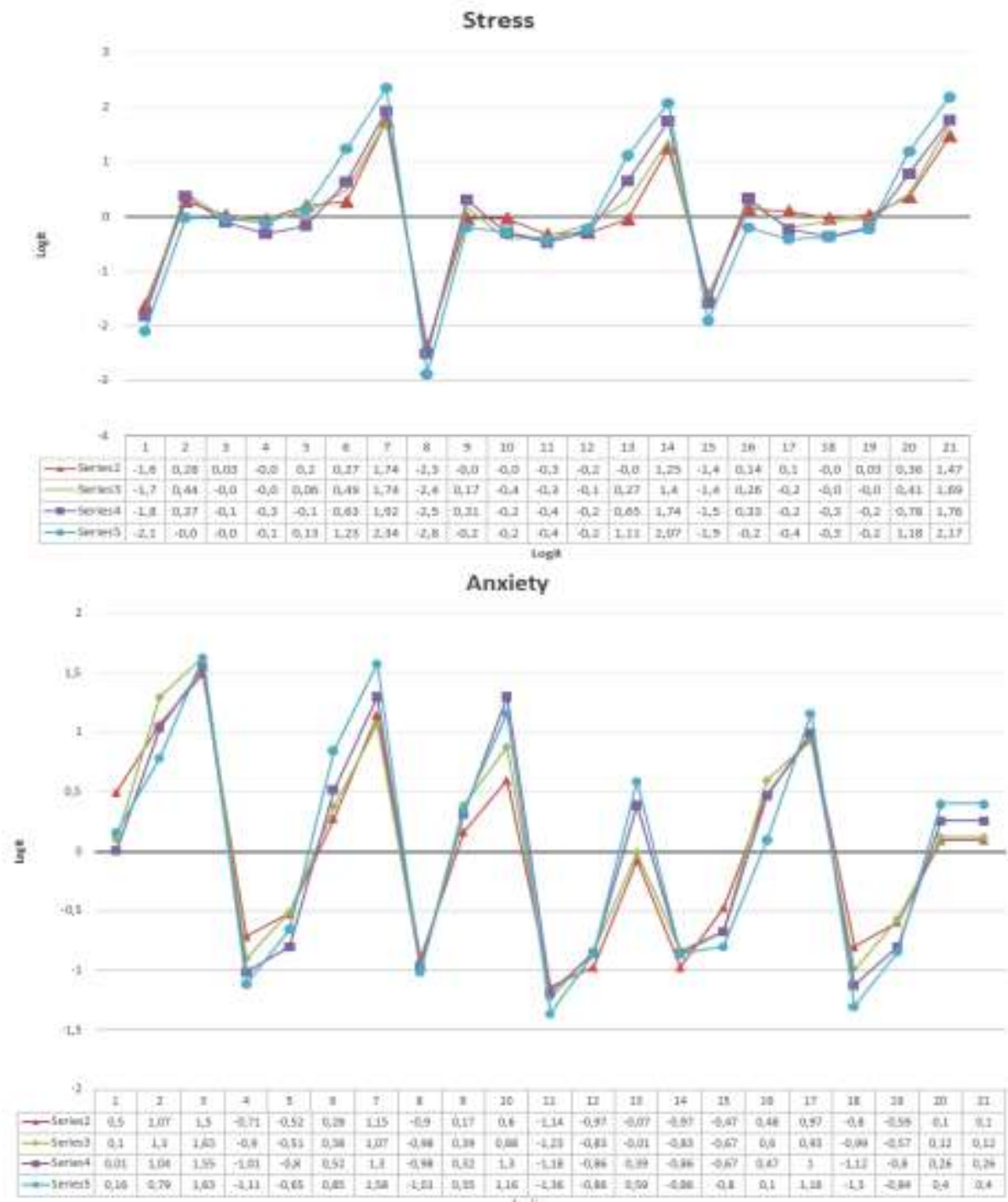

Figure 10. Stress and Anxiety Conditions Based on Internet Time 
Mental resilience and disorders (depression, anxiety, and somatization) have a negative relationship (Naeem, et al., 2020). In the study of Cal, Sá, Glustak, \& Santiago (2015) there was a negative correlation between endurance scores and the development of various diseases and quality of life. While some multimedia-based or face-to-face programs have assessed the usefulness of CBT for resilience in diverse populations (Helmreich et al., 2017; Suranata, Susiani, Susanto, \& Novitasari, 2019), this program has not been used to build resilience in people who face challenging situations to help ease their burden on psychopathological development (Naeem, et al., 2020). CBT is an ideal intervention for victims of natural disasters, wars, earthquakes, trauma, and pandemics (Naeem, et al., 2020; Yang et al., 2018). The results of the study found that adults in Indonesia heard and saw more news related to the COVID-19 pandemic, which eventually individuals imagined COVID-19, thus creating feelings of stress and anxiety in individuals.

\section{Conclusions}

The findings show 82 respondents experienced severe stress conditions, 410 respondents were under moderate stress conditions, 156 respondents were under mild stress conditions, and 11 respondents were under normal stress conditions related to COVID-19. While in anxiety conditions there were 14 respondents who had very severe conditions, 69 respondents were in severe conditions, 412 respondents were in anxious conditions, 104 respondents were in mild anxiety conditions, and 70 respondents were in normal anxiety conditions. The distance between MST (mean, 1SD and 2SD) shows a significant difference between a mean person and mean item, for example, stress instruments which have a mean measure difference of -1.46 and anxiety instruments differing -2.06, meaning the condition of the average respondent in mild circumstances related to the COVID19 pandemic problem. The results of the study show items SHC7 (stress) and AHC3 (anxiety) are the dominant problems in stress and anxiety conditions based on ethnicity, age, number of social media accounts, length of internet access per day. In addition, the number of social media accounts is related to the length of internet access per day, this is because of individuals using the internet to hear or see news related to COVID19 on social media accounts, which individuals imagine COVID-19, thus creating feelings of stress and anxiety in themselves individual. Efforts to reduce it can be done simply by reducing access to social media accounts and reducing internet access. Based on the findings of the need for intervention from a counselor or psychologist to reduce stress conditions that make individuals offended when listening to COVID-19 related and anxious conditions that make hands shake when hearing about COVID-19.

\section{References}

Asmundson, G. J. G., \& Taylor, S. (2020). Coronaphobia: Fear and the 2019-nCoV outbreak. Journal of anxiety disorders, 70, 102196-102196.

Bai, Y., Lin, C. C., Lin, C. Y., Chen, J. Y., Chue, C. M., \& Chou, P. (2004). No Title Survey of stress reactions among health care workers involved with the SARS outbreak. Psychiatr Serv, 55, 1055-1057.

Beyens, I., Frison, E., \& Eggermont, S. (2016). "I don't want to miss a thing": Adolescents' fear of missing out and its relationship to adolescents' social needs, Facebook use, and Facebook related stress. Computers in Human Behavior, 64, 1-8. doi: 10.1016/j.chb.2016.05.083

Bond, T. G., \& Fox, C. M. (2015). Applying the Rasch Model, Fundamental Measurement in the Human Science (3rd Editio ed.). New York: Routledge.

Boone, W. J., Stever, J. R., \& Yale, M. S. (2014). Rasch Analysis in the Human Science. Dordrech: Springer.

Braunack-Mayer, A., Tooher, R., Collins, J. E., Street, J. M., \& Marshall, H. (2013). Understanding the school community's response to school closures during the H1N1 2009 influenza pandemic. BMC public health, 13(1), 344-344.

Brooks, S. K., Webster, R. K., Smith, L. E., Woodland, L., Wessely, S., Greenberg, N., \& Rubin, G. J. (2020). The psychological impact of quarantine and how to reduce it: rapid review of the evidence. The Lancet, 395, 912-920.

Cal, S. F., Sá, L. R. D., Glustak, M. E., \& Santiago, M. B. (2015). Resilience in chronic diseases: A systematic review. Cogent Psychology, 2(1), 1024928-1024928.

Caleo, G., Duncombe, J., Jephcott, F., Lokuge, K., Mills, C., Looijen, E., \& Lamin, M. (2018). The factors affecting household transmission dynamics and community compliance with Ebola control measures: a mixed-methods study in a rural village in Sierra Leone. BMC public health, 18(1), 248-248.

Cheng, P., Xia, G., Pang, P., Wu, B., Jiang, W., Li, Y.-T., . . . Wang, J. (2020). COVID-19 epidemic peer support and crisis intervention via social media. Community mental health journal, 1-7.

Das, N. (2020). Psychiatrist in post-COVID-19 era - are we prepared? Asian Journal of Psychiatry, 102082102082. doi: 10.1016/j.ajp.2020.102082 
Desclaux, A., Badji, D., Ndione, A. G., \& Sow, K. (2017). Accepted monitoring or endured quarantine? Ebola contacts' perceptions in Senegal. Social Science \& Medicine, 178, 38-45.

Dong, L., \& Bouey, J. (2020). Early Release - Public Mental Health Crisis during COVID-19 Pandemic, China. Emerging Infectious Diseases Journal, 26(7).

Goyal, K., Chauhan, P., Chhikara, K., Gupta, P., \& Singh, M. P. (2020). Fear of COVID 2019: First suicidal case in India. Asian journal of psychiatry, 49, 101989-101989.

Helmreich, I., Chmitorz, A., König, J., Binder, H., Wessa, M., Lieb, K., \& Kunzler, A. (2017). Psychological interventions for resilience enhancement in adults. The Cochrane database of systematic reviews, 2, CD012527-CD012527.

Holshue, M. L., DeBolt, C., Lindquist, S., Lofy, K. H., Wiesman, J., Bruce, H., . . Pillai, S. K. (2020). First Case of 2019 Novel Coronavirus in the United States. New England Journal of Medicine, 382, 929-936.

Internet World Stats. (2016). Retrieved from http://www.internetworldstats.com.

Lai, C.-C., Wang, C.-Y., Wang, Y.-H., Hsueh, S.-C., Ko, W.-C., \& Hsueh, P.-R. (2020). Global epidemiology of coronavirus disease 2019 (COVID-19): disease incidence, daily cumulative index, mortality, and their association with country healthcare resources and economic status. International Journal of Antimicrobial Agents.

Li, S., Wang, Y., Xue, J., Zhao, N., \& Zhu, T. (2020). The Impact of COVID-19 Epidemic Declaration on Psychological Consequences: A Study on Active Weibo Users. International Journal of Environmental Research and Public Health, 17(6), 2-9.

Liang, D., Mays, V. M., \& Hwang, W. C. (2018). Integrated mental health services in China: challenges and planning for the futur. Health policy and planning, 33(1), 107-122.

Linacre, J. M. (2011). A User's Guide to WINSTEPS Ministeps Rasch-Model Computer Programs.

Liu, X., Kakade, M., Fuller, C. J., Fan, B., Fang, Y., Kong, J., \& Wu, P. (2012). Depression after exposure to stressful events: lessons learned from the severe acute respiratory syndrome epidemic. Comprehensive psychiatry, 53(1), 15-23.

Mak, I. W. C., Chu, C. M., Pan, P. C., Yiu, M. G. C., \& Chan, V. L. (2009). Long-term psychiatric morbidities among SARS survivors. General hospital psychiatry, 31(4), 318-326.

Naeem, F., Irfan, M., \& Javed, A. (2020). Coping with COVID-19: urgent need for building resilience through cognitive behaviour therapy. Khyber Medical University Journal, 12(1), 1-3.

Naeem, F., Phiri, P., Nasar, A., Gerada, A., Munshi, T., Ayub, M., \& Rathod, S. (2016). An evidence-based framework for cultural adaptation of cognitive behaviour therapy: process, methodology and foci of adaptation. World Cultural Psychiatry Research Review, 11(1), 61-70.

Organization, W. H. (2020). [Rolling updates on coronavirus disease (COVID-19)].

Padesky, C. A., \& Mooney, K. A. (2012). Strengths based cognitive-behavioural therapy: a four-step model to build resilience. Clinical psychology \& psychotherapy, 19(4), 283-290.

Reynolds, D. L., Garay, J. R., Deamond, S. L., Moran, M. K., Gold, W., \& Styra, R. (2008). Understanding, compliance and psychological impact of the SARS quarantine experience. Epidemiology \& Infection, 136(7), 997-1007.

Sumintono, B., \& Widhiarso, W. (2015). Aplikasi Pemodelan Rasch pada Assessment Pendidikan. Bandung: Trim Komunikata.

Suranata, K., Susiani, K., Susanto, E., \& Novitasari, Y. (2019). Evaluation of the Effectiveness of SmartResilience Interventions for Middle School Students: A Pilot Study. IJICC, 5(5), 40-59.

Swainston, J., Chapman, B., Grunfeld, E. A., \& Derakshan, N. (2020). COVID-19 lockdown and its adverse impact on psychological health in breast cancer. Frontiers in Psychology, 11, 2033.

Tosepu, R., Gunawan, J., Savitri, D., Effendy, Ode, L., Imran, A., . . Asfian, P. (2020). Correlation between weather and Covid-19 pandemic in Jakarta, Indonesia. Science of the Total Environment, 725.

Wang, Y., Xu, B., Zhao, G., Cao, R., He, X., \& Fu, S. (2011). Is quarantine related to immediate negative psychological consequences during the $2009 \mathrm{H} 1 \mathrm{~N} 1$ epidemic? General hospital psychiatry, 33(1), 75-77.

Who. (2020a). Coronavirus disease (COVID-19) Weekly Epidemiological Update and Weekly Operational Update, from https://www.who.int/docs/default-source/coronaviruse/situation-reports/20200306

Who. (2020b). Novel coronavirus (2019-nCoV): strategic preparedness and response plan, from https://www.who.int/publications/i/item/strategic-preparedness-and-response-plan-for-the-newcoronavirus

Who. (2020c). Pneumonia of unknown cause-China. Disease outbreak news, from https://www.who.int/csr/don/05-january-2020-pneumonia-of-unkown-cause-china/en/

Wu, P., Fang, Y., Guan, Z., Fan, B., Kong, J., Yao, Z., . . Hoven, C. W. (2009). The psychological impact of the SARS epidemic on hospital employees in China: exposure, risk perception, and altruistic acceptance of risk. The Canadian Journal of Psychiatry, 54(5), 302-311. 
Yang, J. P., Simoni, J. M., Dorsey, S., Lin, Z., Sun, M., Bao, M., \& Lu, H. (2018). Reducing distress and promoting resilience: a preliminary trial of a CBT skills intervention among recently HIV-diagnosed MSM in China. AIDS care, 30(5), 39-48.

Yıldırım, M., \& Güler, A. (2020). Positivity explains how COVID-19 perceived risk increases death distress and reduces happiness. Personality and Individual Differences, 168, 110347. 